\title{
STEROIDS FROM Chisocheton tomentosus
}

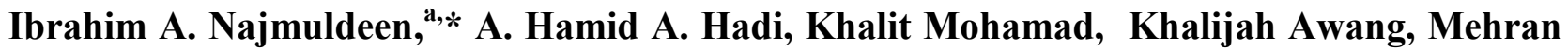 Fadaei Nasab, Kamal Aziz Ketuly, Mat Ropi Mukhtar, and Hiroshi Morita}

\begin{abstract}
${ }^{1}$ Department of Chemistry, Faculty of Science, University Malaya, 50603 Kuala Lumpur, Malaysia, ${ }^{2}$ Department of Pharmacy, Faculty of Medicine, University Malaya, 50603 Kuala Lumpur, Malaysia, ${ }^{3}$ CENAR, Department of Chemistry, Faculty of Science, University Malaya, 50603 Kuala Lumpur, Malaysia, ${ }^{4}$ Faculty of Pharmaceutical Sciences, Hoshi University, Ebara 2-4-41 Shinagawa-ku, Tokyo 142-8501, Japan *shaswary66@yahoo.com(Correspondingauthor)

Received on $20^{\text {th }}$ July 2011, accepted in revised form $23^{\text {rd }}$ July 2011.
\end{abstract}

\begin{abstract}
Four steroids have been isolated from dichloromethane extract of Chisocheton tomentosus (Meliaceace), they were; $7 \alpha$-hydroxy- $\beta$-sitosterol 1, stigmasta-4,6-diene-3-one 2, stigmasterol 3 and sitosterol 4. $7 \alpha$ Hydroxy- $\beta$-sitosterol 1 was isolated as a colourless crystal and this compound was a new compound in crystal structure. The isolation and purification of the compounds were achieved by using column and PTL chromatographic techniques. The compounds were identified by spectroscopic techniques such as UV, IR, MS, 1D, and 2D NMR. In addition; $7 \alpha$-hydroxy - $\beta$-sitosterol was also identified by $\mathrm{X}$-Ray diffraction technique.
\end{abstract}

(Key word: Meliaceace, Chisocheton tomentosus, steroids )

\section{INTRODUCTION}

In continuing of our researches on the Meliaceae genera [1-4], we have studied the phytochemical constituents of the dichloromethane extract of Chisocheton tomentosus (bark). Chisocheton tomentosus is a $14 \mathrm{~m}$ tall and $15 \mathrm{~cm}$ diameter tree with a dark brown bark. There is no phytochemical investigation reported for this plant.

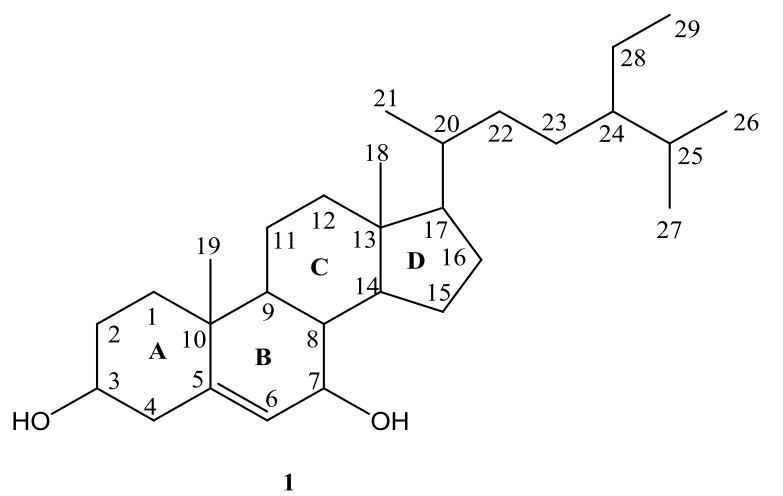

Previous phytochemical studies on Chisocheton species have yielded a number of interesting bioactive compounds including limonoids, antifungal meliacinetype compounds, spermidine alkaloids, sesquiterpenes, and dammarane triterpenoids with an inhibibitory effect on Epstein-Barr virus activation [5-10]. In this work, we report the isolation and characterization of four steroids isolated from Chisocheton tomentosus.<smiles>CCC(CCC(C)C1CCC2C3=CCC4=CC(=O)CCC4(C)C3CCC21C)C(C)C</smiles> 


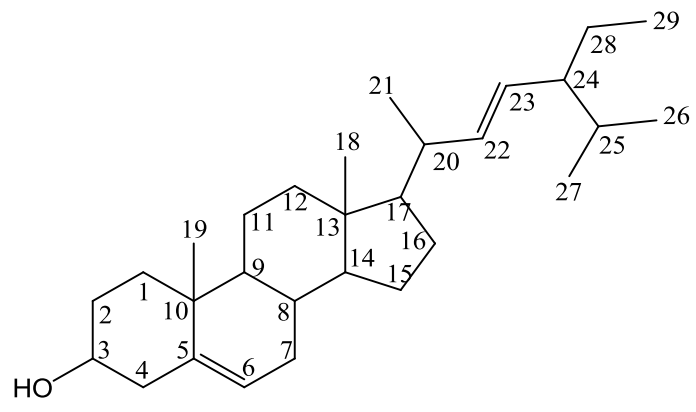

3

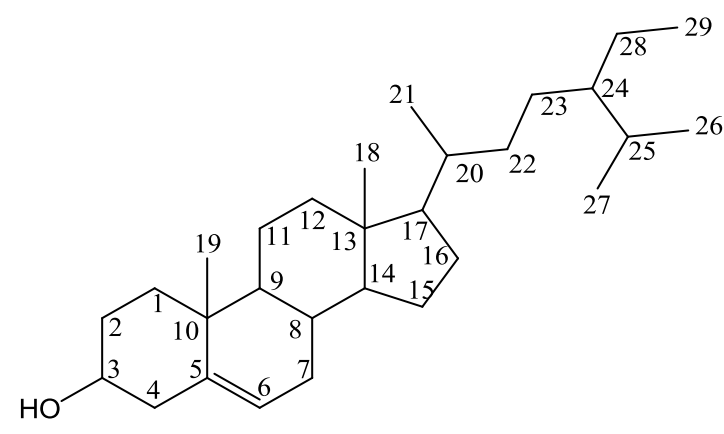

4
$7 \alpha$-Hydroxy- $\beta$-sitosterol $\mathbf{1}$ was isolated as a colorless crystal mp $138-140{ }^{\circ} \mathrm{C}$, the UV spectrum showed absorption at $\lambda_{\max } 302 \mathrm{~nm}$ and $254 \mathrm{~nm}$. The IR spectrum indicated the presence of hydroxyl group by the absorption band at $v_{\max } 3430 \mathrm{~cm}^{-1}$; the GCMS spectrum revealed a molecular ion peaks $[\mathrm{M}]^{+}$at $\mathrm{m} / \mathrm{z}$ 430 , corresponding for molecular formula $\mathrm{C}_{29} \mathrm{H}_{50} \mathrm{O}_{2}$.

The ${ }^{1} \mathrm{H}-\mathrm{NMR}$ spectrum (Table 1) of $\mathbf{1}$ showed six methyl groups resonated as singlet, doublet and triplet in the region of $\delta_{\mathrm{H}} 0.65-0.95$. A characteristic doublet for H-6 methine proton appeared at $\delta_{\mathrm{H}} 5.55$ indicating the presence of double bond functionality between $\mathrm{C}-5$ and C-6, two downfield signals at $\delta 3.81$ and 3.54 were assigned to the $\mathrm{H}-7$ and $\mathrm{H}-3$ respectively, indicating to the presence of oxygen functionality at their carbons.
The ${ }^{13} \mathrm{C}$ - NMR spectrum (Table 2) of $\mathbf{1}$ displayed twenty-nine carbon atoms in the molecule. The DEPT spectrum exhibited six methyls, ten methylenes and ten methines, while the remaining three carbons were quaternary. No signals was observed beyond $\delta_{\mathrm{C}} 146.3$ and, therefore, it was concluded that no ketonic function in this molecule. The downfield signals at $\delta_{\mathrm{C}}$ 146.3 was attributed to olefinic quaternary carbon, the C-6 olefinic methine carbon appeared at $\delta_{\mathrm{C}} 123.8$, two more signals for oxygen-bearing carbons at $\delta_{\mathrm{C}} 71.3$ and 65.4 were ascribed to $\mathrm{C}-3$ and $\mathrm{C}-7$ respectively.

The COSY spectrum indicated the presence of two major spin systems, spin system "a" and spin system "b". Spin system "a" started with the couplings of C-3 proton with the $\mathrm{C}-4$ methylene protons, meanwhile, spin system "b" the olefinic proton of C-6 showed vicinal connectivity with $\mathrm{C}-7$ methineproton.

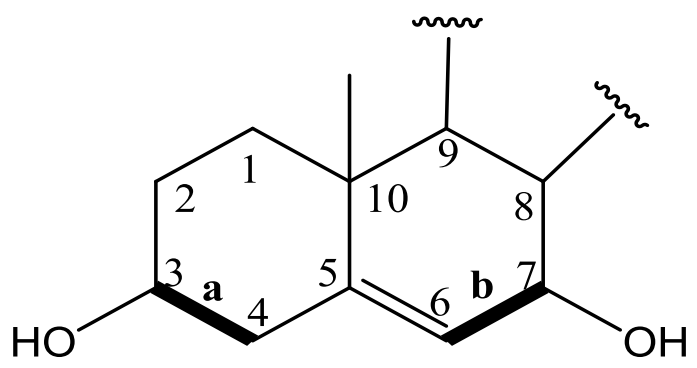

selected ${ }^{1} \mathrm{H}-{ }^{1} \mathrm{H}$ COSY of Compound $\mathbf{1}$ 
Table 1. ${ }^{1} \mathrm{H}-\mathrm{NMR}\left(400 \mathrm{MHz}\right.$, in $\mathrm{CDCl}_{3}$ ) spectral data for compounds $\mathbf{1 , 2}, \mathbf{3}$, and 4

\begin{tabular}{|c|c|c|c|c|}
\hline \multirow[b]{2}{*}{ Positions } & \multicolumn{4}{|c|}{$\delta_{\mathrm{H}}($ int.; mult.; $J(\mathrm{~Hz}))$} \\
\hline & 1 & 2 & 3 & 4 \\
\hline $1 \mathrm{a}$ & $1.80(1 \mathrm{H}, \mathrm{m})$ & $1.96(1 \mathrm{H}, \mathrm{m})$ & $1.81(1 \mathrm{H}, \mathrm{m})$ & $1.81(1 \mathrm{H}, \mathrm{m})$ \\
\hline $1 b$ & $1.01(1 \mathrm{H}, \mathrm{m})$ & $1.70(1 \mathrm{H}, \mathrm{m})$ & $1.04(1 \mathrm{H}, \mathrm{m})$ & $1.04(1 \mathrm{H}, \mathrm{m})$ \\
\hline $2 \mathrm{a}$ & $1.80(1 \mathrm{H}, \mathrm{m})$ & $2.55(1 \mathrm{H}, \mathrm{m})$ & $1.79(1 \mathrm{H}, \mathrm{m})$ & $1.79(1 \mathrm{H}, \mathrm{m})$ \\
\hline $2 b$ & $1.47(1 \mathrm{H}, \mathrm{m})$ & $2.42(1 \mathrm{H}, \mathrm{m})$ & $1.50(1 \mathrm{H}, \mathrm{m})$ & $1.50(1 \mathrm{H}, \mathrm{m})$ \\
\hline 3 & $3.54(1 \mathrm{H}, \mathrm{m})$ & & $3.51(1 \mathrm{H}, \mathrm{m})$ & $3.46(1 \mathrm{H}, \mathrm{m})$ \\
\hline 4 & $2.29(2 \mathrm{H}, \mathrm{d}, 5)$ & $5.64(1 \mathrm{H}, \mathrm{s})$ & $2.27(2 \mathrm{H}, \mathrm{m})$ & $2.27(2 \mathrm{H}, \mathrm{m})$ \\
\hline 6 & $5.55(1 \mathrm{H}, \mathrm{d}, 5.04)$ & $6.06(1 \mathrm{H}, \mathrm{dd}, 10,2.5)$ & $5.32(1 \mathrm{H}, \mathrm{m})$ & $5.32(1 \mathrm{H}, \mathrm{m})$ \\
\hline 7 & $3.81(1 \mathrm{H}, \mathrm{brs})$ & $6,09(1 \mathrm{H}, \mathrm{t}, 10)$ & $1.93(2 \mathrm{H}, \mathrm{m})$ & $1.93(2 \mathrm{H}, \mathrm{m})$ \\
\hline 8 & $1.43(1 \mathrm{H}, \mathrm{m})$ & $2.18(1 \mathrm{H}, \mathrm{m})$ & $1.45(1 \mathrm{H}, \mathrm{m})$ & $1.45(1 \mathrm{H}, \mathrm{m})$ \\
\hline 9 & $1.15(1 \mathrm{H}, \mathrm{m})$ & $1.18(1 \mathrm{H}, \mathrm{m})$ & $0.92(1 \mathrm{H}, \mathrm{m})$ & $0.92(1 \mathrm{H}, \mathrm{m})$ \\
\hline 11 & $1.49(2 \mathrm{H}, \mathrm{m})$ & $1.57(2 \mathrm{H}, \mathrm{m})$ & $1.50(2 \mathrm{H}, \mathrm{m})$ & $1.50(2 \mathrm{H}, \mathrm{m})$ \\
\hline $12 \mathrm{a}$ & $1.97(1 \mathrm{H}, \mathrm{m})$ & $2.05(1 \mathrm{H}, \mathrm{m})$ & $1.95(1 \mathrm{H}, \mathrm{m})$ & $1.95(1 \mathrm{H}, \mathrm{m})$ \\
\hline $12 \mathrm{~b}$ & $1.12(1 \mathrm{H}, \mathrm{m})$ & $1.24(1 \mathrm{H}, \mathrm{m})$ & $1.17(1 \mathrm{H}, \mathrm{m})$ & $1.17(1 \mathrm{H}, \mathrm{m})$ \\
\hline 14 & $1.41(1 \mathrm{H}, \mathrm{m})$ & $1.25(1 \mathrm{H}, \mathrm{m})$ & $1.00(1 \mathrm{H}, \mathrm{m})$ & $1.00(1 \mathrm{H}, \mathrm{m})$ \\
\hline $15 \mathrm{a}$ & $1.66(1 \mathrm{H}, \mathrm{m})$ & $1.77(1 \mathrm{H}, \mathrm{m})$ & $1.54(1 \mathrm{H}, \mathrm{m})$ & $1.54(1 \mathrm{H}, \mathrm{m})$ \\
\hline $15 b$ & $1.08(1 \mathrm{H}, \mathrm{m})$ & $1.25(1 \mathrm{H}, \mathrm{m})$ & $1.04(1 \mathrm{H}, \mathrm{m})$ & $1.04(1 \mathrm{H}, \mathrm{m})$ \\
\hline 16 & $1.83(2 \mathrm{H}, \mathrm{m})$ & $1.54(2 \mathrm{H}, \mathrm{m})$ & $1.65(2 \mathrm{H}, \mathrm{m})$ & $1.65(2 \mathrm{H}, \mathrm{m})$ \\
\hline 17 & $1.14(1 \mathrm{H}, \mathrm{m})$ & $1.14(1 \mathrm{H}, \mathrm{m})$ & $1.12(1 \mathrm{H}, \mathrm{m})$ & $1.12(1 \mathrm{H}, \mathrm{m})$ \\
\hline 18 & $0.65(3 \mathrm{H}, \mathrm{s})$ & $0.74(3 \mathrm{H}, \mathrm{s})$ & $0.67(3 \mathrm{H}, \mathrm{s})$ & $0.65(3 \mathrm{H}, \mathrm{s})$ \\
\hline 19 & $0.95(3 \mathrm{H}, \mathrm{s})$ & $1.09(3 \mathrm{H}, \mathrm{s})$ & $1.00(3 \mathrm{H}, \mathrm{s})$ & $1.00(3 \mathrm{H}, \mathrm{s})$ \\
\hline 20 & $1.33(1 \mathrm{H}, \mathrm{m})$ & $1.36(1 \mathrm{H}, \mathrm{m})$ & $2.00(1 \mathrm{H}, \mathrm{m})$ & $1.41(1 \mathrm{H}, \mathrm{m})$ \\
\hline 21 & $0.89(3 \mathrm{H}, \mathrm{d}, 6.4)$ & $0.90(3 \mathrm{H}, \mathrm{m})$ & $0.98(3 \mathrm{H}, \mathrm{m})$ & $0.98(3 \mathrm{H}, \mathrm{m})$ \\
\hline 22 & $1.24(2 \mathrm{H}, \mathrm{m})$ & $1.36(2 \mathrm{H}, \mathrm{m})$ & $5.09(1 \mathrm{H}, d, 15.1)$ & $1.32(2 \mathrm{H}, \mathrm{m})$ \\
\hline 23 & $1.22(2 \mathrm{H}, \mathrm{m})$ & $1.30(2 \mathrm{H}, \mathrm{m})$ & $4.96(1 \mathrm{H}, d, 15.1)$ & $1.33(2 \mathrm{H}, \mathrm{m})$ \\
\hline 24 & $0.93(1 \mathrm{H}, \mathrm{m})$ & $0.90(1 \mathrm{H}, \mathrm{m})$ & $1.52(1 \mathrm{H}, \mathrm{m})$ & $1.47(1 \mathrm{H}, \mathrm{m})$ \\
\hline 25 & $1.64(1 \mathrm{H}, \mathrm{m})$ & $1.66(1 \mathrm{H}, \mathrm{m})$ & $1.53(1 \mathrm{H}, \mathrm{m})$ & $1.47(1 \mathrm{H}, \mathrm{m})$ \\
\hline 26 & $0.81(3 \mathrm{H}, \mathrm{m})$ & $0.81(3 \mathrm{H}, \mathrm{m})$ & $0.83(3 \mathrm{H}, \mathrm{m})$ & $0.80(3 \mathrm{H}, \mathrm{m})$ \\
\hline 27 & $0.77(3 \mathrm{H}, \mathrm{m})$ & $0.77(3 \mathrm{H}, \mathrm{m})$ & $0.80(3 \mathrm{H}, \mathrm{m})$ & $0.78(3 \mathrm{H}, \mathrm{m})$ \\
\hline 28 & $1.22(2 \mathrm{H}, \mathrm{m})$ & $1.22(2 \mathrm{H}, \mathrm{m})$ & $1.43(2 \mathrm{H}, \mathrm{m})$ & $1.21(2 \mathrm{H}, \mathrm{m})$ \\
\hline 29 & $0.83(3 \mathrm{H}, \mathrm{m})$ & $0.83(3 \mathrm{H}, \mathrm{m})$ & $0.81(3 \mathrm{H}, \mathrm{t})$ & $0.89(3 \mathrm{H}, \mathrm{m})$ \\
\hline
\end{tabular}


Table 2. ${ }^{13} \mathrm{C}-\mathrm{NMR}\left(100 \mathrm{MHz}\right.$, in $\left.\mathrm{CDCl}_{3}\right)$ spectral data for compounds $\mathbf{1}, \mathbf{2}, \mathbf{3}$, and $\mathbf{4}$

\begin{tabular}{|c|c|c|c|c|}
\hline \multirow[b]{2}{*}{ Positions } & \multicolumn{4}{|c|}{$\delta^{13} \mathrm{C}$} \\
\hline & 1 & 2 & 3 & 4 \\
\hline 1 & 37.08 & 39.9 & 37.2 & 37.2 \\
\hline 2 & 31.3 & 34.0 & 29.7 & 31.6 \\
\hline 3 & 71.3 & 199.8 & 71.8 & 71.8 \\
\hline 4 & 42.0 & 123.5 & 42.3 & 39.8 \\
\hline 5 & 146.3 & 164.2 & 140.7 & 140.7 \\
\hline 6 & 123.8 & 127.8 & 121.7 & 121.7 \\
\hline 7 & 65.4 & 141.8 & 31.9 & 31.9 \\
\hline 8 & 37.5 & 37.8 & 31.9 & 31.9 \\
\hline 9 & 42.3 & 50.7 & 50.1 & 50.1 \\
\hline 10 & 37.4 & 36.1 & 36.5 & 36.5 \\
\hline 11 & 20.7 & 20.7 & 21.1 & 21.1 \\
\hline 12 & 39.2 & 39.6 & 39.7 & 42.3 \\
\hline 13 & 42.2 & 43.5 & 42.2 & 42.3 \\
\hline 14 & 49.4 & 53.4 & 56.8 & 56.7 \\
\hline 15 & 24.3 & 23.8 & 24.3 & 24.3 \\
\hline 16 & 28.3 & 26.1 & 28.9 & 28.2 \\
\hline 17 & 55.7 & 56.0 & 55.9 & 56.0 \\
\hline 18 & 11.7 & 11.9 & 12.0 & 11.8 \\
\hline 19 & 19.2 & 16.4 & 19.4 & 19.4 \\
\hline 20 & 36.1 & 36.2 & 40.5 & 36.1 \\
\hline 21 & 18.3 & 18.7 & 21.2 & 18.8 \\
\hline 22 & 33.8 & 34.9 & 138.3 & 33.9 \\
\hline 23 & 29.8 & 28.3 & 129.2 & 26.0 \\
\hline 24 & 49.4 & 45.9 & 51.2 & 45.8 \\
\hline 25 & 29.0 & 29.1 & 31.9 & 29.1 \\
\hline 26 & 19.9 & 19.9 & 21.1 & 19.8 \\
\hline 27 & 18.9 & 19.0 & 19.9 & 19.0 \\
\hline 28 & 23.1 & 23.1 & 25.4 & 23.0 \\
\hline 29 & 12.1 & 12.0 & 12.2 & 12.0 \\
\hline
\end{tabular}




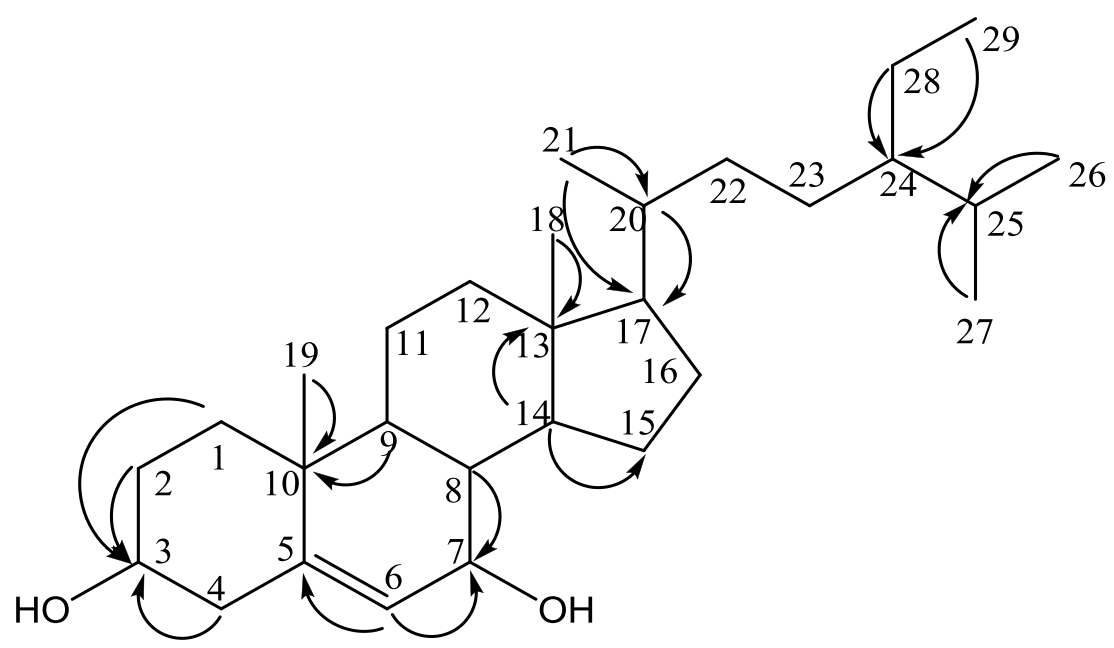

Selected HMBC Correlations of Compound $\mathbf{1}$

HMBC spectrum of 1 showed correlation of $\mathrm{H}_{3}-19$ to C-10 , similarly $\mathrm{H}_{3}-18$ to $\mathrm{C}-13$. It means that the methyl group at $\mathrm{C}-19$ and $\mathrm{C}-18$ should be attached directly to $\mathrm{C}-10$ and $\mathrm{C}-13$ respectively. Other protons to carbon connectivity were shown in the following structure.

Based on the spectral data and comparison with literature review [11-14], it was concluded that the steroid 1 was $7 \alpha$-hydroxy- $\beta$-sitosterol. This was further supported by X-Ray reflection technique.

4,6-Stigmastadiene-3-one 2, was isolated as white amorphous, UV spectrum showed an absorption at $\lambda_{\max } 282 \mathrm{~nm}$. The IR spectrum indicated the presence of conjugated ketone at $v_{\max } 1670,1620,1588$, and $875 \mathrm{~cm}^{-1}$ indicating the presence of conjugated diene. The LCMS spectrum revealed a molecular ion peaks $[\mathrm{M}]^{+}$at $\mathrm{m} / \mathrm{z} 410$ corresponding for molecular formula $\mathrm{C}_{29} \mathrm{H}_{46} \mathrm{O}$

The ${ }^{1} \mathrm{H}-\mathrm{NMR}$ spectrum (Table 1) of $\mathbf{2}$ closely resembled compound $\mathbf{1}$ ( $7 \alpha$-hydroxy $\beta$-sitosterol). It showed six methyl groups resonated as singlet, doublet and triplet in the region of $\delta_{\mathrm{H}}$ 0.74-1.09. A diagnostic downfield signals at $\delta_{\mathrm{H}} 5.64$ (singlet), 6.06 (dd, $J_{6,7}=10 \mathrm{~Hz}, J_{6,4}=2.5 \mathrm{~Hz}$ ), and 6.09 (triplet, $J_{7,6}$ and $J_{7,8}=10 \mathrm{~Hz}$ ) were ascribed to C-4, C-6, C-7 olefinic protons, respectively. Downfield multiplet signals at $\delta_{\mathrm{H}} 2.55$ and 2.42 were attributed to two geminal protons of $\mathrm{C}-2$ vicinal to ketone, the multiplicity signals of $\mathrm{C}-2$ protons again indicated the presence of carbonyl at vicinal C-3. This indicated the presence of 4,6-diene-3-oxo system in the ring $\mathbf{A}$ and $\mathbf{B}$.

The ${ }^{13} \mathrm{C}$-NMR spectrum (Table 2) of 2 displayed twenty-nine carbon signals; the DEPT spectra indicated the presence of six methyl, nine methylene and ten methine carbons, while the remaining four carbons were quaternary as deduced from broadband spectrum. The downfield signals at $\delta_{\mathrm{C}} 199.8$ were assigned to the 3-oxo-carbon, the signals at $\delta_{\mathrm{C}} 123.5$, $164.2,127.8$, and 141.8 were ascribed to the olefinic C-4, C-5, C-6, and C-7 respectively. By comparison with the reported data, compound 2 was identified as a known stigmasta-4,6-diene-3-one.

The COSY spectrum indicated the presence of two major selected fragments, spin system in the fragment "a" and spin system in the fragment "b". Spin system "a" started with the couplings of C-1 methylene protons with the $\mathrm{C}-2$ methylene protons, meanwhile, spin system "b" started with the couplings of olefinic proton of C-6 with C-7 methine proton which in turn showed couplings with $\mathrm{C}-8$ methine proton and so on. These homonuclear couplings helped in the construction of the double bond in the fragment "b" which conjugated with the double bond of C-4 and C-5. 


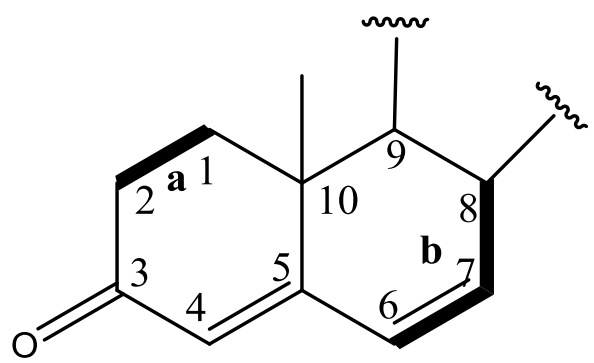

selected ${ }^{1} \mathrm{H}-{ }^{1} \mathrm{H}$ COSY of Compound 2

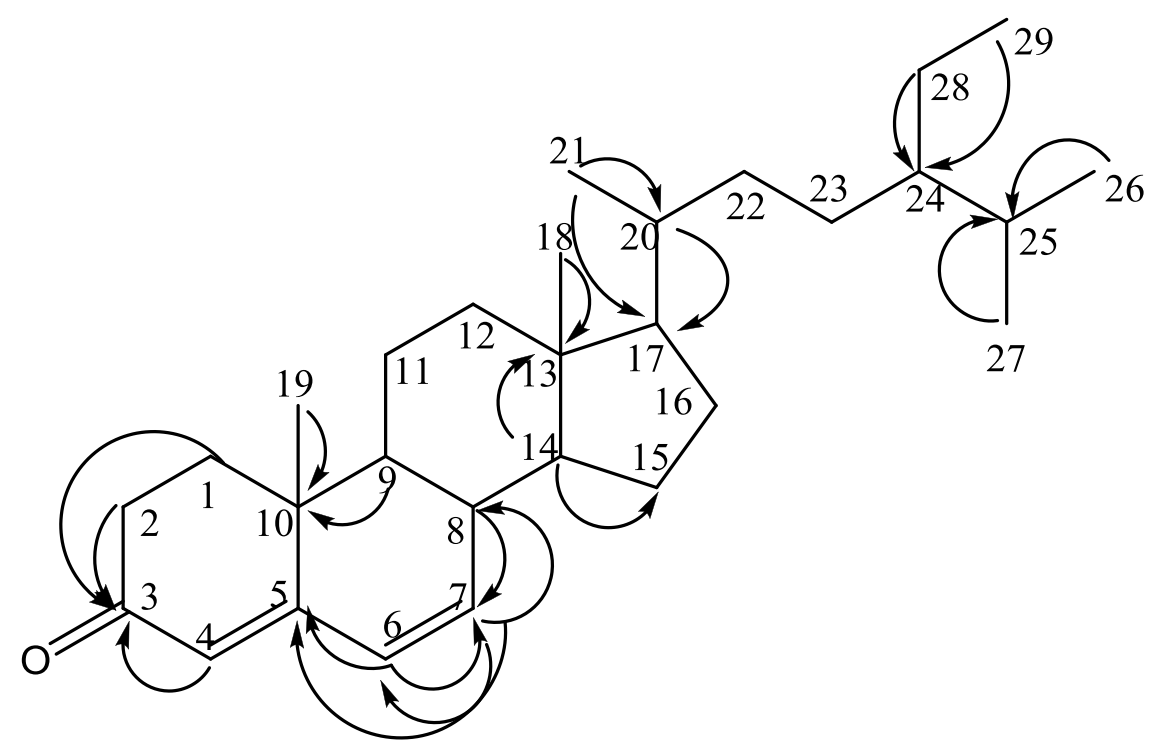

\section{Selected HMBC Correlations of Compound 2}

The $\mathrm{H}_{3}-19$ at junction of rings $\mathbf{A}$ and $\mathbf{B}$ showed HMBC connectivity with $\mathrm{sp}^{3}$ quaternary carbon of C$10, \mathrm{sp}^{2}$ quaternary carbon of C-5, methylene of C-1 and methine carbon of C-9. Similarly, C-2 methylene protons showed HMBC correlations with ketonic carbon at C-3 and methylene carbon of C-1, indicating that the ketone should be at the position $\mathrm{C}$ 3. By comparing the spectral data and LCMS of $\mathbf{2}$ with reported data [15-16], the compound 2 was identified as stigmasta-4,6-diene-3-one.

Compound $\mathbf{3}$ and $\mathbf{4}$ were isolated as a mixture of a white solid with the same $\mathrm{R}_{f}$ values. The UV spectrum showed absorption bands at $\lambda_{\max } 302$ and $254 \mathrm{~nm}$. The infrared spectrum indicated the presence of hydroxyl group by the absorption bands at $v_{\max } 3430 \mathrm{~cm}^{-1}$. The presence of stigmasterol 3 and 4 was confirmed by the LCMS showing a molecular peak $[\mathrm{M}+\mathrm{H}]^{+}$at $m / z, 413$ and 415 , corresponding to the molecular formula $\mathrm{C}_{29} \mathrm{H}_{49} \mathrm{O}$ and $\mathrm{C}_{29} \mathrm{H}_{51} \mathrm{O}$ respectively.

Sterols with an ethyl group at C-24, such as stigmasterol and $\beta$-sitosterol are by far the most abundant compounds in most plants. The mixture of these two compounds was analyzed by ${ }^{1} \mathrm{H}$ and ${ }^{13} \mathrm{C}$ NMR spectroscopy. The ${ }^{1} \mathrm{H}-\mathrm{NMR}$ spectrum (Table 1) of this mixture showed twelve methyl groups (six methyl groups for each compound) resonated as singlet, doublet and triplet in the region of $\delta_{\mathrm{H}} 0.65$ 1.00. A methine proton attached to C-6 of both compounds resonated further downfield as a doublet at $\delta_{\mathrm{H}} 5.32$, the most significant differences shown by the ${ }^{1} \mathrm{H}-\mathrm{NMR}$ chemical shift of these two molecules were the proton signals of C-22 and C-23. In compound 3 , the presence of a double bond at position C-22 gave rise to two-doublet of a doublet signals at $\delta_{\mathrm{H}} 4.96$ and 5.09 which belong to $\mathrm{H}-23$, 
and $\mathrm{H}-22$, respectively. In compound $\mathbf{4}$, the protons of two methylene groups at $\mathrm{C}-22$ and $\mathrm{C}-23$, gave rise

as multiplets in the region of $\delta_{\mathrm{H}} 0.90-2.00$. The rest of the protons resonated as multiplets in the region of $\delta_{\mathrm{H}}$ 0.7-3.5.

The integration of $\mathrm{H}-6, \mathrm{H}-22$ and $\mathrm{H}-23$ appeared to be in the ratio of 1:0.25:0.25. Therefore, it could be deduced that the mixture of isolated stigmasterol and $\beta$-sitosterol was in the ratio of approximately 1:2.

Since compound $\mathbf{3}$ and $\mathbf{4}$ have an identical sterol skeleton, the ${ }^{13} \mathrm{C} / \mathrm{DEPT}$ spectra (Table 2) of this mixture showed quite similar chemical shifts. The most significant differences on the chemical shift of

\section{Experimental Part}

\section{General Methods}

All solvents used in this experiment are distilled industrial grade. Silica gel 60, 230-400 mesh ASTM (Merck 9385) was used for column chromatography. A slurry of silica gel 60 (approximately 30:1 silica gel to sample ratio). The NMR spectra were obtained using JEOL LA400 FT NMR and JEOL ECA400 FT NMR Spectrometer System using deuterated chloroform as solvent. Chemical shifts were reported in ppm and coupling constants were given in Hertz $(\mathrm{Hz})$. Mass spectra were carried out on Agilent Technologies 6530 Accurate-Mass Q-TOF LC/MS, with ZORBAX Eclipse XDB-C18 Rapid Resolution HT 4.6 mmi.d. x $50 \mathrm{~mm}$ x $1.8 \mu \mathrm{m}$ column, the EI MS spectra were obtained on Shimadzu GC-MS QP2000A spectrometer $70 \mathrm{eV}$, the high-resolution ESI MS were measured on a LTQ Orbitrap XL (Thermo Scientific). UV spectra were recorded on a Shimadzu UV-Visible Recording Spectrophotometer using HPLC grade ethanol as solvent with mirror UV cell.The infrared (IR) spectra were obtained through Perkin Elmer FT-IR Spectrometer Spectrum RX1 using chloroform as solvent. Melting points were taken on hot stage Gallen Kamp melting point these two molecules were the signals of C-22 and C23For compound $\mathbf{3}$, the $\mathrm{sp}^{2}$ carbons; C-22 and C-23 resonated at $\delta_{\mathrm{C}} 138.3$ and 129.2 , respectively.

The presence of the double bond also moved C-20, C-21, C-24, C-25 and C-28 further downfield at $\delta_{\mathrm{C}}$ $40.5,21.2,51.2,31.9$ and 25.4 respectively, as compared to that of compound $\mathbf{4}$, which showed the signals at $\delta_{\mathrm{C}} 36.1,18.8,45.8,29.1$ and 23.1 for C-20, C-21, C-24, C-25 and C-28, respectively.

By comparing the NMR spectra data with the literature value [17-23], it was confirmed that compound $\mathbf{3}$ was stigmasterol and compound $\mathbf{4}$ was $\beta$-sitosterol.

apparatus and were uncorrected.

\section{Plant Materials}

Bark of Chisocheton tomentosus was collected and identified from Mersing Johor, Malaysia in 1993 by the team of Herbarium of Chemistry Department, University of Malaya, Kuala Lumpur, Malaysia. It has been deposited in the above herbarium under voucher specimens KL 4251.

\section{Extraction and Isolation}

The ground and dried bark of Chisocheton tomentosus ( $1.0 \mathrm{~kg}$ ) was first extracted using hexane for 3 to 5 days followed by $\mathrm{CH}_{2} \mathrm{Cl}_{2}$ and $\mathrm{MeOH}$. Then, the $\mathrm{CH}_{2} \mathrm{Cl}_{2}$ extract underwent the fractionation using silica gel column chromatography. The fractions from the column were subjected to thin layer chromatography (TLC) and further purified by preparative TLC and microcolumn. The structures of isolated compounds were determined by spectroscopic methods such as UV, Infrared, 1D and 2D Nuclear Magnetic Resonance, Mass Spectroscopy as well as X-Ray reflectometer. Figure 1 showed the extraction and isolation procedures of steroids from Chisocheton tomentosus. 


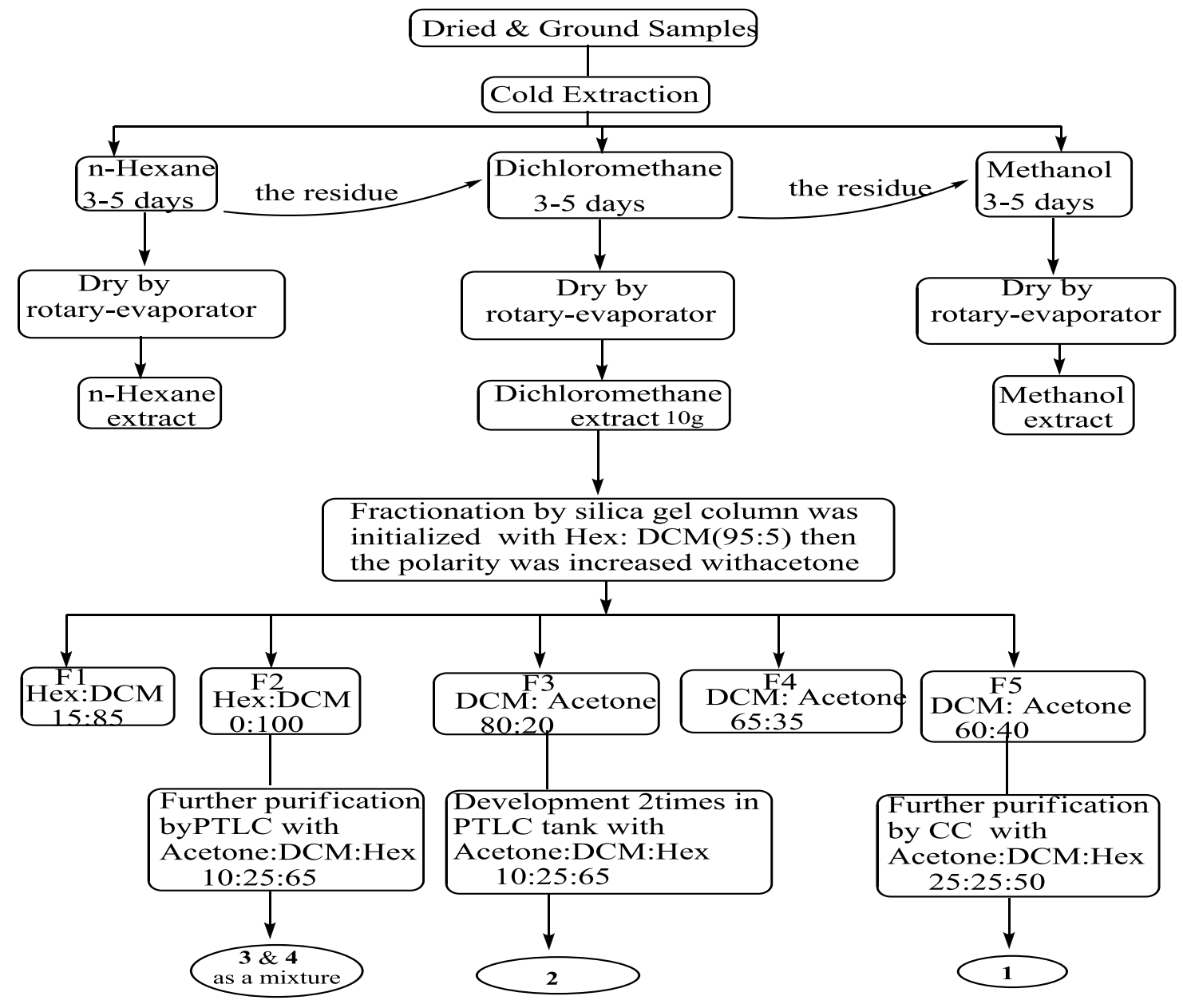

Figure 1. Extraction and isolation of chemical constituents from Chisocheton tomentosus

\section{ACKNOWLEDGEMENTS}

This work was supported by a Grant from a collaborative research between ICSN, CNRS, France and University of Malaya and a Grant from CENAR. This work was also partly supported by a Grant-inAid for Scientific Research from the Ministry of Education, Culture, Sports, Science, and Technology of Japan, and a grant from the Open Research Center Project, and finally the first author would like to thank Kurdistan of Iraq for scholarship.

\section{REFERENCES}

1. Najmuldeen, I. A., Hadi, A. H. A., Awang, K., Mohamad, K., and Ng, S. W. (2008) 17(5-Ethyl-6-methylheptan-2-yl)-10,13dimethyl-
2,3,4,7,8,9,10,11,12,13,14,15,16,17tetradecahydro- $1 \mathrm{H}$ -

cyclopenta[a]phenanthrene-3,7-diol from Chisocheton tomentosus (Meliaceae), Acta Crystallogr., Sect. E: Struct. Rep. Online E64, o2163, o2163/2161-o2163/2116.

2. Najmuldeen, I. A., Hadi, A. H. A., Awang, K., Mohamad, K., Ketuly, K. A., Mukhtar, M. R., Chong, S.-L., Chan, G., Nafiah, M. A., Weng, N. S., Shirota, O., Hosoya, T., Nugroho, A. E., and Morita, H. (2011) Chisomicines A-C, Limonoids from Chisocheton ceramicus, J. Nat. Prod. 74, 1313-1317.

3. Najmuldeen, I. A., Abdul, H. A. H., Awang, K., Mohamad, K., and Ng, S. W. (2010) 5- 
Hydroxy-7-methoxy-2-methyl-4Hchromen-4-one from Dysoxylum macrocarpum (Meliaceae), Acta Crystallogr., Sect. E: Struct. Rep. Online E66, o1883.

4. Najmuldeen, I. A., Abdul, H. A. H., Awang, K., Mohamad, K., and Ng, S. W. (2010) 14Deoxyxyloccensin $\mathrm{K}$ from Chisocheton ceramicus (Meliaceae), Acta Crystallogr., Sect. E: Struct. Rep. Online E66, o1927.

5. Gunning, P. J., Jeffs, L. B., Isman, M. B., and Towers, G. H. N. (1994) Two limonoids from Chisocheton microcarpus, Phytochemistry 36, 1245-1248.

6. Inada, A., Somekawa, M., Murata, H., Nakanishi, T., Tokuda, H., Nishino, H., Iwashima, A., Darnaedi, D., and Jurata, J. (1993) Phytochemical studies on meliaceous plants. VIII. Structures and inhibitory effects on Epstein-Barr virus activation of triterpenoids from leaves of Chisocheton macrophyllus King, Chem. Pharm. Bull. 41, 617-619.

7. Awang, K., Lim, C. S., Mohamad, K., Morita, H., Hirasawa, Y., Takeya, K., Thoison, O., and Hadi, A. H. A. (2007) Erythrocarpines A-E, new cytotoxic limonoids from Chisocheton erythrocarpus, Bioorganic \& Medicinal Chemistry 15, 5997-6002.

8. Bordoloi, M., Saikia, B., Mathur, R. K., and Goswami, B. N. (1993) A meliacin from Chisocheton paniculatus, Phytochemistry 34, 583-584.

9. Phongmaykin, J., Kumamoto, T., Ishikawa, T., Suttisri, R., and Saifah, E. (2008) A new sesquiterpene and other terpenoid constituents of Chisocheton penduliflorus, Arch Pharm Res 31, 21-27.

10. Kongduang, D., Wungsintaweekul, J., and De-Eknamkul, W. (2008) Biosynthesis of $\beta$ sitosterol and stigmasterol proceeds exclusively via the mevalonate pathway in cell suspension cultures of Croton stellatopilosus, Tetrahedron Lett. 49, 40674072 .
11. Topcu, G., Tan, N., Kokdil, G., and Ulubelen, A. (1997) Terpenoids from Salvia glutinosa, Phytochemistry 45, 1293-1294.

12. Gunatilaka, A. A. L., Samaranvayake, G., and Kingston, D. G. I. (1992) Bioactive ergost-5-ene-3 $\beta, 7 \alpha$-diol derivatives from Pseudobersama mossambicensis, J. Nat. Prod. 55, 1648-1654.

13. Schroeder, G., Rohmer, M., Beck, J. P., and Anton, R. (1980) 7-Oxo-, 7 $\alpha$-hydroxy-, and 7 $\beta$-hydroxysterols from Euphorbia fischeriana, Phytochemistry 19, 2213-2215.

14. Foley, D. A., O'Callaghan, Y., O'Brien, N. M., McCarthy, F. O., and Maguire, A. R. (2010) Synthesis and Characterization of Stigmasterol Oxidation Products, J. Agric. Food Chem. 58, 1165-1173.

15. Akihisa, T., Kimura, Y., Roy, K., Ghosh, P., Thakur, S., and Tamura, T. (1994) Triterpene alcohols and 3-oxo steroids of nine Leguminosae seeds, Phytochemistry 35, 1309-1313.

16. Conner, A. H., Nagasampagi, B. A., and Rowe, J. W. (1980) Terpenoid and other extractives of western white pine bark, Phytochemistry 19, 1121-1131.

17. Forgo, P., and Kövér, K. E. (2004) Gradient enhanced selective experiments in the $1 \mathrm{H}$ NMR chemical shift assignment of the skeleton and side-chain resonances of stigmasterol, a phytosterol derivative, Steroids 69, 43-50.

18. Xu, W. L., Huang, Y. B., Qian, J. H., Sha, O., and Wang, Y. Q. (2005) Separation and purification of stigmasterol and [beta]sitosterol from phytosterol mixtures by solvent crystallization method, Separation and Purification Technology 41, 173-178.

19. De-Eknamkul, W., and Potduang, B. (2003) Biosynthesis of [beta]-sitosterol and stigmasterol in Croton sublyratus proceeds via a mixed origin of isoprene units, Phytochemistry 62, 389-398.

20. Säynäjoki, S., Sundberg, S., Soupas, L., Lampi, A.-M., and Piironen, V. (2003) 
Determination of stigmasterol primary oxidation products by high-performance liquid chromatography, Food Chemistry 80 , 415-421.

21. Huang, X., and Kong, L. (2006) Steroidal saponins from roots of Asparagus officinalis, Steroids 71, 171-176.

22. Manoharan, K. P., Benny, T. K. H., and Yang, D. (2005) Cycloartane type triterpenoids from the rhizomes of Polygonum bistorta, Phytochemistry 66, 2304-2308.

23. Lendl, A., Werner, I., Glasl, S., Kletter, C., Mucaji, P., Presser, A., Reznicek, G., Jurenitsch, J., and Taylor, D. W. (2005) Phenolic and terpenoid compounds from Chione venosa (sw.) urban var. venosa (Bois Bandé), Phytochemistry 66, 23812387. 